\title{
Identification of genetic variability among isolates of Fusarium oxysporum f. sp. vasinfectum of cotton
}

\author{
Kelen R.P. Bibanco ${ }^{1}$, Maria Paula Nunes ${ }^{1}$, Edivaldo $\mathrm{Cia}^{2}$, Maria A. Pizzinatto ${ }^{2}$, Ivan Schuster ${ }^{3}$ \& Yeshwant \\ R. Mehta ${ }^{1}$
}

${ }^{1}$ Instituto Agronômico do Paraná - IAPAR, 86001-970, Londrina, PR, Brazil; ${ }^{2}$ Instituto Agronômico de Campinas - IAC, 13020-902, Campinas, SP, Brazil; ${ }^{3}$ Cooperativa Central de Pesquisa Agrícola - Coodetec, 85813-450, Cascavel, PR, Brazil

Author for correspondence: Yeshwant R. Mehta, e-mail: yrmehta@iapar.br

\begin{abstract}
Fusarium wilt of cotton caused by Fusarium oxysporum f.sp. vasinfectum (FOV) causes yield losses, especially in the States of São Paulo and Paraná. The disease can mainly be controlled by the use of resistant cultivars, and knowledge regarding the genetic diversity among isolates of the pathogen has become essential. Diversity among 15 isolates collected from different Brazilian cotton-producing States was studied along with one isolate of $F$. solani, using molecular techniques. The results of RAPD, PCR-RFLP of rDNA, ERIC and REP-PCR were comparable with each other and indicated the existence of genetic variability among some of the FOV isolates of different geographic origins. This indicates the necessity of using different FOV isolates that represent the genetic diversity of the population, while screening cultivars for genetic resistance against this disease, so that only cultivars that are resistant to isolates from different geographic origins may be used in breeding programs.
\end{abstract}

Key words: Gossypium hirsutum, Fusarium wilt, molecular markers.

\section{RESUMO}

Identificação de variabilidade genética entre isolados de Fusarium oxysporum f. sp. vasinfectum do algodoeiro

A murcha de Fusarium causada por Fusarium oxysporum f.sp. vasinfectum (FOV) provoca perdas no rendimento de algodão principalmente nos estados do Paraná e São Paulo. O controle dessa doença pode ser obtido por meio de resistência varietal, e para este fim, o conhecimento da diversidade genética dentro da população do patógeno é um pré-requisito. Estudou-se a diversidade de 15 isolados de FOV coletados de diversos estados brasileiros, juntamente com um isolado de $F$. solani da soja para fins de comparação, com técnicas moleculares. Os resultados de ERIC e REP-PCR, RAPD e PCR-RFLP de rDNA foram comparáveis e demonstraram existência de variabilidade genética entre isolados de FOV inclusive aqueles provenientes de regiões geograficamente diferentes. Os resultados indicam a necessidade de utilização de isolados que representem a diversidade genética da população nos trabalhos de melhoramento genético visando desenvolver cultivares resistentes a fusariose.

Palavras-chave: Gossypium hirsutum, Fusariose, marcadores moleculares.

Fusarium wilt of cotton caused by Fusarium oxysporum f.sp. vasinfectum (FOV) causes yield losses in the States of São Paulo and Paraná. The disease can be controlled by the use of resistant cultivars. Knowledge regarding the genetic diversity among the isolates of the pathogen has become essential. While the diversity among isolates of FOV has been studied in the USA and France (Armstrong \& Armstrong, 1978; Assigbetse et al., 1994; Edel et al., 1995), there is no information available in Brazil. Using a set of differential cultivars, six physiological races of this pathogen were identified in the USA (Armstrong \& Armstrong, 1978). The objective of the present investigation was to study the variability of Brazilian isolates of FOV using the molecular techniques RAPD, PCR-RFLP of rDNA, ERIC and REP-PCR.

Isolates of FOV were obtained from samples collected during 2001 and 2002 from different cotton cultivars grown in the States of Paraná, São Paulo, Mato Grosso, and Goiás. Fifteen monosporic isolates were used for the present study. One isolate of $F$. solani from soybean was also included for comparison (Table 1). Pathogenicity of all the isolates was studied under glass-house conditions using a susceptible cultivar of cotton and soybean (Bugbee \& Sappenfield, 1968; Wellman, 1939). Fungal cultures were grown in the dark using potato dextrose broth in a rotary shaker for 4 days at $21^{\circ} \mathrm{C}$. Mycelium was filtered through Whatman No. 1 filter paper, washed twice with TE buffer $(10 \mathrm{mM}$ TrisHCL; 1 mM EDTA, $\mathrm{pH}$ 8.0) and total DNA extracted as described by Raeder \& Broda (1985).

The RAPD reactions were performed as reported elsewhere (Williams et al., 1990), and when repeated consistent results were obtained we tested 60 decamer primers (Operon Technologies Inc. Alameda, USA) against six randomly selected isolates. Several bands were either 
TABLE 1 - Isolates of Fusarium oxysporum f. sp vasinfectum (FOV), and F. solani (FS) from soybean used in the present study

\begin{tabular}{|c|c|c|c|c|c|}
\hline $\begin{array}{c}\text { Identification } \\
\text { number }\end{array}$ & Isolate code & Cultivar & LocationYear & $\begin{array}{c}\text { Colony } \\
\text { character }\end{array}$ & Pathogenicity* \\
\hline 1 & FOV 13431 & Unknown & Unknown SP / 1999 & Purple & + \\
\hline 2 & FOV 13561 & IAC 20233 & Caiabú SP / 2002 & Purple & + \\
\hline 3 & FOV 13562 & Unknown & Birigui SP / 2002 & White & + \\
\hline 4 & FOV 13563 & Unknown & Marabá Paulista SP / 2002 & Salmon & + \\
\hline 5 & FOV 13564 & Unknown & Adamantina SP / 2002 & Purple & + \\
\hline 6 & FOV 13565 & CNPA Acala1 & Caiabú SP / 2002 & Purple & + \\
\hline 7 & FOV 13566 & Unknown & Votuporanga SP / 2002 & Purple & + \\
\hline 8 & FOV 13567 & Unknown & Ituverava SP / 2002 & Purple & + \\
\hline 9 & FOV 13578 & Unknown & Juranda PR / 2002 & Purple & + \\
\hline 10 & FOV 13596 & Epamig Alva & Votuporanga SP / 2002 & Purple & + \\
\hline 11 & FOV 13597 & Makina & Miquenópolis SP / 2002 & Purple & + \\
\hline 12 & FOV 13598 & Unknown & Ituverava SP / 2002 & Purple & + \\
\hline 13 & FOV 15520 & Unknown & Rondonópolis MT / 2002 & Purple & + \\
\hline 14 & FOV 15521 & Unknown & Santa Helena GO / 2002 & Purple & + \\
\hline 15 & FOV 902 & ROM 3 & Umuarama PR / 1997 & Purple & + \\
\hline $16^{* *}$ & FS 13364 & Unknown & Unknown PR / 1999 & White & - \\
\hline
\end{tabular}

*Pathogenicity was tested on cultivar Acala 1, using "Root Dip Method" (Bugbee \& Sappenfield, 1968); += positive, -= negative; **F. solani from soybean.

monomorphic or polymorphic, and six primers were used for the present study. RAPD data were analyzed, considering presence or absence of the bands. A cluster analysis was conducted with the unweighted pair group method with arithmetic mean (UPGMA), using the Jaccard coefficient, in the NTSYS-pc program, version 1.8.

The primers REP1/REP2 and ERIC1/ERIC2 (Versalovic et al., 1991) were obtained from Life Technologies and were used to amplify DNA of the fungal isolates. PCR reactions were performed according to Mehta et al. (2002) in a final volume of $25 \mu \mathrm{L}$ containing $10 \mathrm{mM}$ Tris- $\mathrm{HCl}(\mathrm{pH} 8.3), 50 \mathrm{mM} \mathrm{KCl}, 2 \mathrm{mM} \mathrm{MgCl}$, $200 \mathrm{uM}$ of dNTP, $1.3 \mu \mathrm{L}$ of BSA (1\%), $50 \mathrm{M}$ of each primer, $100 \mathrm{ng}$ of genomic DNA, and 1 unit of Taq polymerase (GE healthcare). Amplification products $(25 \mu \mathrm{L})$ were electrophoresed in $2 \%$ agarose gels with TBE buffer, stained with ethidium bromide. ERIC and REP analyses were repeated once and only reproducible bands were scored. Data were analyzed considering the presence or the absence of bands. A distance matrix was constructed as described for RAPD.

The ITS region of the DNA of the isolates was amplified using the primer pair ITS5/ITS4 (White et al., 1990) and the amplification product was digested using six randomly selected restriction enzymes (Alu I, Bgl II, Dra I, Eco R1, Hind III, and Pst I). Aliquots of $5 \mu \mathrm{L}$ of amplification products were submitted to electrophoresis in
$2 \%$ agarose gels and stained with ethidium bromide. The reaction product of $20 \mu \mathrm{L}$ contained $1.5 \mu \mathrm{L}$ of the restriction enzyme.

RAPD analysis revealed seven monomorphic bands and 16 polymorphic bands. The isolates basically formed three distinct groups showing 8 and 52\% index of dissimilarity. However, out of the 16 isolates, 13 formed one group of less than $8 \%$ of dissimilarity. Two isolates from São Paulo State, 13562 and 13563, formed a different group (Figure 1). The banding patterns obtained by ERIC and REP-PCR showed two monomorphic and seven polymorphic bands. The isolates formed five groups between 12 and $56 \%$ of dissimilarity (Figure 2).

RAPD and ERIC - REP produced different dissimilarity index in the present study. However, the grouping of different isolates was consistent in these two methods of analysis. Isolates FS 13364 and FOV 13562 showed a very different banding pattern from the other isolates using these two methods, whereas the rest of the isolates formed one group with higher genetic similarity. Only isolates FOV 13364 and FOV 13562 differed from the major group formed by all the other isolates, using these two methods (Figures 1 and 2).

The amplification product of the ITS region resulted in a fragment size of approximately $900 \mathrm{bp}$ for all the isolates of FOV and approximately $980 \mathrm{bp}$ for the isolate of $F$. solani of soybean. Restriction enzymes Alu1 and 


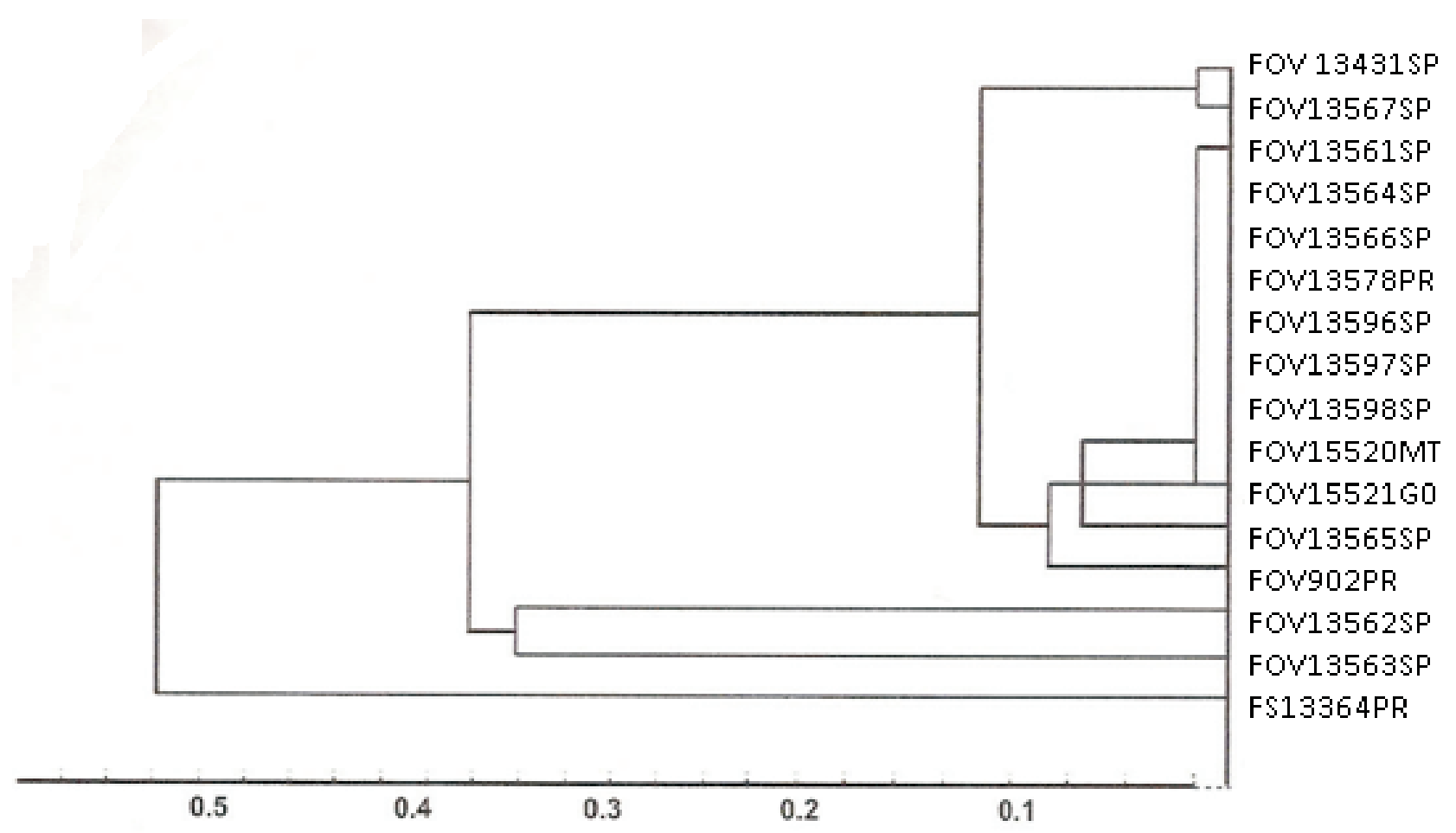

FIGURE 1 - Dendrogram produced by UPGMA cluster analysis based on the Jaccard dissimilarity matrix using six RAPD primers and 15 isolates of Fusarium oxysporum $\mathrm{f}$. sp. vasinfectum (FOV) and one isolate of F. solani (FS) from soybean (No. FS 13364). See Table 1 for details of the isolates.

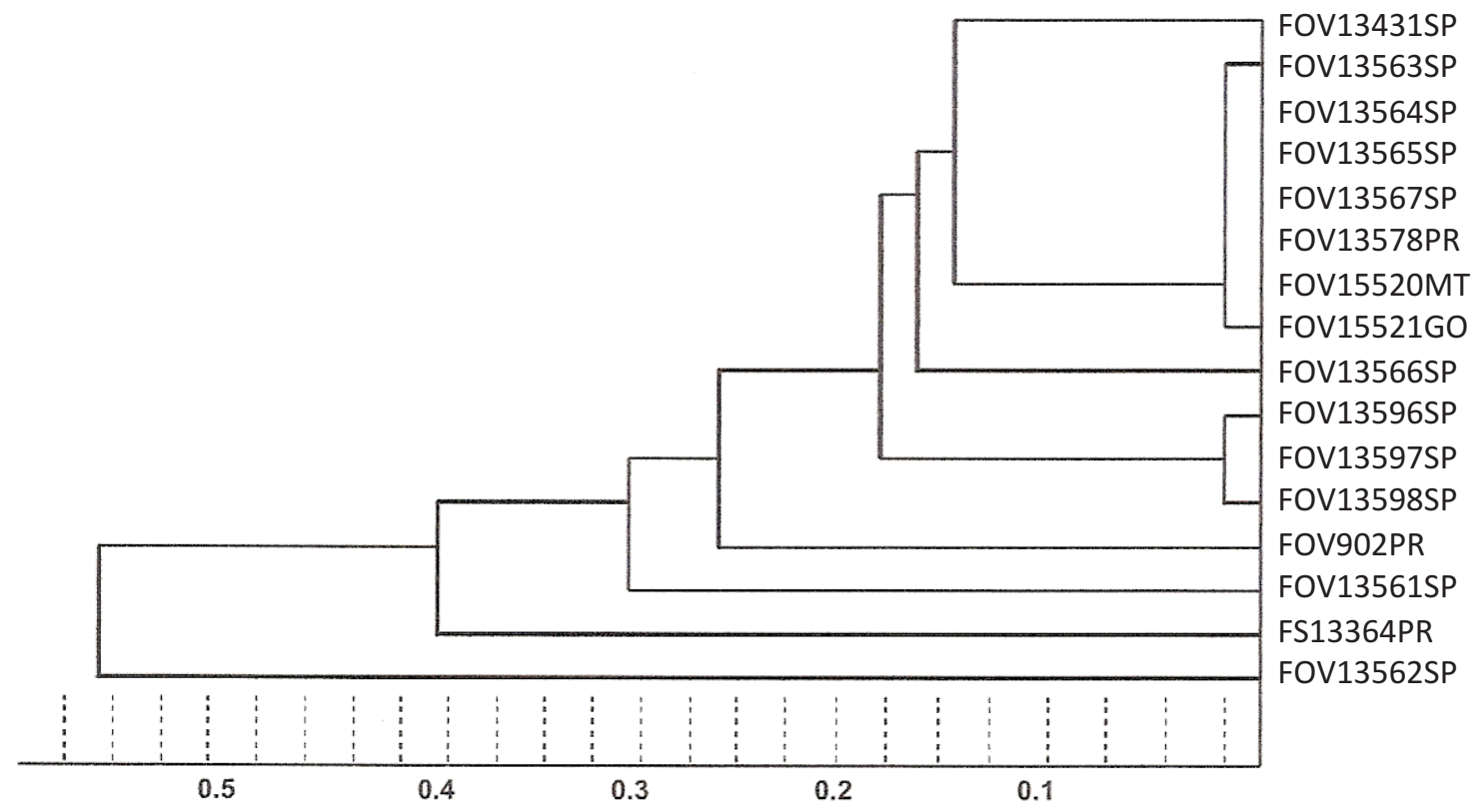

FIGURE 2 - Dendrogram produced by UPGMA cluster analysis based on the Jaccard dissimilarity index using the primer pairs ERIC 1/ERIC2 and REP1/REP2, and 15 isolates of Fusarium oxysporum f. sp. vasinfectum and one isolate of F. solani from soybean (No. FS 13364). See Table 1 for details of the isolates. 
EcoR1, which digested the ITS region, produced similar banding pattern for all the isolates. The restriction enzyme Alu 1 produced two bands, one of approximately $600 \mathrm{bp}$ and the other of approximately $300 \mathrm{bp}$. While the restriction enzyme EcoR 1 produced two bands of approximately 450 bp, the restriction enzymes $B g l$ II, Dra I, Hind III, and Pst I did not produce polymorphic bands. The results of ERIC and REP-PCR, RAPD and PCR-RFLP of rDNA were comparable to each other and demonstrated the existence of genetic variability between some of the FOV isolates. This indicates the necessity of utilizing different isolates while screening cultivars for genetic resistance against this disease. Only the cultivars that are resistant to different isolates may be used in breeding programs aimed at creating cotton cultivars resistant to FOV. The $F$. solani isolate from soybean was completely different from the other cotton isolates.

The results confirmed the expected genetic differences between FOV isolates and $F$. solani isolate. Differences in pathogenicity among the FOV isolates were not detected, probably because only one cotton cultivar susceptible to FOV (Acala 1) was used. Therefore, the differences observed among the isolates using molecular techniques cannot be attributed to the differences in physiological races. Assigbetse et al. (1994) identified three races of FOV, using five differential cotton cultivars, and reported that the isolates of these three races were also grouped in three different banding patterns obtained from RAPD analysis. In this study we have verified the existence of genetic variability among some of the Brazilian FOV isolates. The results obtained herewith form the basis for future research aimed at verifying genetic and physiological differences among a larger number of FOV isolates collected from other cotton growing areas of Brazil.

\section{REFERENCES}

Armstrong GM, Armstrong J (1978) A new race (Race 6) of Fusarium oxysporum f.sp. vasinfectum from Brazil. Plant Disease Reporter 62:421-423.

Assigbetse KB, Fernandez, MP, Dubois MP, Geiger JP (1994) Differentiation of Fusarium oxysporum f.sp. vasinfectum races on cotton by random amplified polymorphic DNA (RAPD) analysis. Phytopathology 84:622-626.

Bugbee WM, Sappenfield WP (1968) Varietal reaction of cotton after stem and root inoculation with Fusarium oxysporum f. sp. vasinfectum. Phytopathology 58:212-214.

Edel V, Steinberg C, Avelange I, Alabouvette C (1995) Comparison of three methods for the characterization of Fusarium oxysporum strains. Phytopathology 85:579-585.

Mehta YR, Mehta A, Rosato YB (2002) ERIC and REP-PCR banding patterns and sequence analysis of the internal transcribed spacer of rDNA of Stemphylium solani from cotton. Current Microbiology 44:323-328.

Raeder U, Broda P (1985) Rapid preparation of DNA from filamentous fungi. Letters Applied Microbiology 18:6503-6508.

Versalovic J, Koeuth T, Lupski JR (1991) Distribution of repetitive DNA sequences in eubacteria and application to fingerprinting of bacterial genomes. Nucleic Acids Research 19:6823-6831.

Wellman FL (1939) A technique for studing host resistance and pathogenicity in tomato fusarium wilt. Phytopathology 29:945-955.

White TJ, Bruns T, Lee S, Tayler J (1990). Amplification and direct sequencing of fungal ribosomal RNA genes for polygenetics. In: Innis MA, Gelfand DH, Sninsky JJ, White TJ (Eds.) PCR protocols: a guide to methods and applications. San Diego CA. Academic Press. pp. 315-322.

Williams JGK, Kubelik AR., Rafalski JA, Tingex SV (1990) DNA polymorphism amplified by arbitrary primers are useful as genetic markers. Nucleic Acid Research 18:6531-6535. 